\title{
Peranan metakognitif dalam pembelajaran dan pengajaran biologi di kelas
}

\author{
Lina Listiana ${ }^{1 *}$, Ruspeni Daesusi ${ }^{2}$, Sandha Soemantri $^{3}$ \\ Universitas Muhammadiyah Surabaya \\ 1 linalistiana521@gmail.com*; ilma_nisa001@yahoo.co.id; sandhasoemantri@gmail.com \\ *korespondensi penulis
}

\begin{abstract}
Abstrak
Pembelajaran dan pengajaran biologi merupakan proses yang kompleks terkait permasalahannya dan keterampilan berpikir mendalam untuk memahaminya. Permasalahan sulit berkenaan dengan kehidupan adalah tantangan tersendiri mendorong siswa menjadi pemecahan masalah yang handal. Untuk itu perlu strategi pembelajaran yang membantu melatihkan siswa dalam memecahkan permasalahan. Metakognitif merupakan kegiatan mengontrol secara sadar tentang proses kognitifnya sendiri. Strategi metakognitif atau regulasi adalah proses-proses yang berfokus pada planning, monitoring, controling dan evaluation. Kemampuan melakukan perencanaan, pemantauan, control, dan evaluasi sangat penting dalam mengembangkan keterampilan pemecahan masalah. Siswa yang sadar atas aktivitas berpikir atau belajarnya sendiri adalah siswa yang memiliki keterampilan metakognitif. Model metakognitif merupakan model yang melibatkan kemampuan berpikir dan proses refleksi selama pembelajaran. Model metakognitif diterapkan pada pembelajaran meliputi lima komponen utama, (1) mempersiapkan dan merencanakan pembelajaran, (2) memilih dan menggunakan strategi, (3) menggunakan strategi serta melakukan pemantauan, (4) mengatur berbagai strategi, (5) mengevaluasi penggunaan strategi dan belajar. Metakognitif memegang peranan penting dalam pembelajaran, oleh sebab itu guru harus merancang pembelajaran yang mempromosikan metakognitif mulai pada kegiatan awal pembelajaran, kegiatan inti, dan kegiatan setelah pembelajaran. Namun demikian terdapat beberapa hambatan dalam penerapan metakognitif, baik hambatan secara umum maupun kesulitan secara khusus. Disamping itu ternyata dampak penerapan metakognitif dalam pembelajaran biologi sangat besar dalam meningkatkan kemampuan berpikir tingkat tinggi yaitu kemampuan pemecahan masalah, pengambilan keputusan, berpikir kritis dan berpikir kreatif.
\end{abstract}

Kata kunci: metakognitif, pembelajaran, pengajaran, biologi.

\section{Abstract}

Biology learning and teaching is a complex process related to the problem and deep thinking skills to understand it. Difficult problems relating to life are separate challenges pushing students into reliable problem solving. For that we need a learning strategy that helps train students in solving problems. Metacognitive is the activity of consciously controlling the cognitive processes themselves. Metacognitive strategies or regulations are processes that focus on planning, monitoring, controling and evaluating. The ability to plan, monitor, control and evaluate is very important in developing problem solving skills. Students who are aware of their own thinking or learning activities are students who have metacognitive skills. The metacognitive model is a model that involves thinking skills and the process of reflection during learning. The metacognitive model applied to learning includes five main components, (1) preparing and planning 
learning, (2) choosing and using strategies, (3) using strategies and monitoring, (4) managing various strategies, (5) evaluating the use of strategies and learning. Metacognitive plays an important role in learning, therefore teachers must design learning that promotes metacognitive starts at the beginning of learning activities, core activities, and activities after learning. However, there are some obstacles in the application of metacognitive, both in general and in particular difficulties. Besides that it turns out the impact of the application of metacognitive in biological learning is very large in improving the ability to think at a higher level, namely the ability of problem solving, decision making, critical thinking and creative thinking.

Keywords: metacognitive, learning, teaching, biology

\section{PENDAHULUAN}

Perkembangan pendidikan di abad ke 21 ini menuntut banyak perubahan dalam segala aspek pembelajaran dan pengajaran. Sistem pendidikan kita masih didominasi dosen atau guru sebagai instruktur dibandingkan fasilitator, metode ceramah sebagian masih banyak diterapkan daripada metode inovatif, Pendekatan pembelajaran Students Center Learning (SCL) masih belum banyak diterapkan. Demikian pula sistem penilaian masih sangat berorientasi pada hasil bukan proses. Sementara kompetensi peserta didik dituntut memiliki keterampilan berpikir tinggi, berpikir kritis, berpikir kreatif, metakognitif, kemampuan berkolaboratif, berkomunikasi, dan menjadi pemecah masalah handal.

Sistem pendidikan yang berorientasi pada proses memberikan ruang pada penyelesaian masalah yang flesibel. Pemecahan masalah akan tumbuh dengan sendirinya jika peserta didik belajar dengan baik di kelas. Pemecahan masalah tidak lagi menunggu tumbuhnya, tetapi perlu diajarkan langsung oleh guru sebagai objek pembelajaran. Melalui pemecahan masalah memberikan kesempatan siswa untuk membangun konsep dan mengembangkan keterampilan berpikirnya sendiri. Agar dapat menyelesaikan suatu masalah maka siswa harus memiliki kemampuan metakognitif. Sementara pengembangan metakognitif siswa seolah terbelenggu dengan pembelajaran kita yang dikejar tayang seperti penyelesain materi, berbagai jenis ujian dengan bentuk pilihan ganda, dan masih ada lagi faktor lain sehingga metakognitif sulit diterapkan.

Pembelajaran biologi tidak hanya memahami dan menghafal fakta-fakta, konsep, dan teori, tetapi lebih dari itu pembelajaran dengan kegiatan belajar aktif menggunakan pikiran untuk mencari solusi pemecahan masalah. Pembelajaran seharusnya tidak memberikan solusi tetapi diarahkan untuk menggali informasi, mengkonstruksi, menggunakan keterampilan kognitifnya dalam menentukan strategi memecahkan masalah. Guru diharapkan dapat 
memfasilitasi pengembangan metakognitif siswa antara lain dengan pemberian tugas-tugas kompleks yang menuntut kemampuan pemecahan masalah.

Kemampuan metakognitif merujuk pada kemampuan siswa berpikir tentang proses berpikirnya (thinking about thinking) (Livingston, 1997). Proses berpikir mengarahkan pada pembelajaran yang mendalam, bagaimana siswa belajar, mengontrol proses belajar mulai merencanakan tindakan, menentukan strategi yang tepat sesuai masalah yang dihadapi, kemudian memonitor kemajuan dalam belajar dan mengoreksi kesalahan serta menganalisis konsep dan strategi yang ditentukan. Dengan metakognitif siswa mampu membangun pengetahuan sendiri, menentukan strategi yang akan digunakan pemecahan masalah, dan mampu mengontrol hasil belajar.

Berdasarkan hal-hal yang dikemukakan di atas, maka dapat dikatakan bahwa metakognitif memiliki peranan dalam mengatur dan mengontrol proses-proses kognitif dalam belajar, sehingga belajar dilakukan dengan efisien dan efektif. Dengan demikian pengembangan metakognitif penting diberdayakan dalam proses pembelajaran dan pengajaran serta asesmen.

\section{PEMBAHASAN}

\section{Pengertian Metakognitif}

Metakognisi (metacognition) merupakan suatu istilah yang diperkenalkan oleh Flavell (1979), yaitu sebagai pengetahuan seseorang tentang proses kognitifnya. Metakognitif pada dasarnya merupakan kegiatan "thinking about thinking", yaitu merupakan kegiatan mengontrol secara sadar tentang proses kognitifnya sendiri. Kegiatan metakognitif meliputi kegiatan berfikir untuk merencanakan, memonitoring, merefleksi bagaimana menyelesaikan suatu masalah (Livingston, 1997). Siswa yang memiliki kesadaran metakognitif tahu apa yang harus dilakukan ketika mereka tidak tahu. Siswa itulah memiliki strategi metakognitif untuk mencari tahu apa yang harus dilakukan. Penggunaan strategi metakognitf akan mendorong pemikiran dan mengarah pada pembelajaran yang lebih mendalam.

Menurut Flavell, metakognitif meliputi dua komponen yaitu: 1) pengetahuan metakognitif (metakognitive knowledge); dan 2) pengalaman/regulasi metakognitif (metakognitive experience or regulation) atau disebut juga strategi metakognitif (dikutip Livingston, 1997). Pengetahuan metakognitif dibagi menjadi 3 kategori yaitu (1) variabel individu, mengetahui bahwa kita semua adalah organisme kognitif atau pemikir artinya segala tindak-tanduk kita adalah akibat dari cara kita berpikir; (2) variabel tugas, mengetahui 
keperluan suatu tugas kognitif; dan (3) variabel strategi, pengetahuan tentang bagaimana melakukan sesuatu atau mengatasi kesulitan yang ada (Flavell, 1979). Pengetahuan tentang tugas yakni termasuk hal-hal seperti tuntutan tugas kognitif, tujuan, kesulitan, kompleksitas, dan konteks (Pintrich, 2002; Taricone, 2011), dan pengetahuan tentang strategi yakni meliputi pembelajaran, strategi pemecahan masalah, dan strategi penyelesaian tugas spesifik (Whitebread, 2007), serta kapan dan dimana menggunakan strategi.

Regulasi atau strategi metakognitif merupakan proses-proses yang berfokus pada planning, monitoring, controling dan evaluation. Perencanaan metakognitif merupakan kegiatan yang mengintegrasikan unsur-unsur metakognitif seperti merencanakan penyelesaian tugas, membagi tugas yang kompleks, dan memprediksi hasil tugas (Whitebread, 2007; Schraw, \& Moshman, 1995). Pemantauan merupakan kegiatan refleksi, melihat kemajuan, keadaan menggunakan strategi yang dipilh (Whitebread, 2007; Ambrose, et al. 2010). Kegiatan kontrol adalah respons dari temuan pemantauan refleksi, misalnya mengubah strategi dan menyesuaikan tujuan. Evaluasi adalah proses refleksi setelah selesai menyelesaikan tugas, bagaimana hasil dari tugas dan belajar (Schraw, \& Moshman, 1995). Strategi metakognitif sangat penting untuk menentukan keefektifan pembelajaran, karena memungkinkan siswa merencanakan strategi, kemudian melakukan pemantauan serta mengendalikan dan melakukan evaluasi pembelajaran.

Keterampilan metakognitif merupakan sebuah proses regulasi, metakognitif sebagai sebuah kesadaran aktivitas diri sendiri. Keterampilan metakognitif terlihat dalam proses pembelajaran maupun dalam keterampilan belajar untuk belajar (teaching to learn) yang dapat dipindahkan ke situasi belajar yang baru. Adanya keterampilan pada diri siswa akan mengarahkan pilihan siswa untuk menentukan apa yang harus dilakukan selama proses belajar atau memecahkan masalah untuk mencapai tujuan belajar (Brown, 1987). Keterampilan metakognitif diyakini memegang peranan penting pada banyak tipe aktivitas kognitif termasuk pemahaman, komunikasi, perhatian (attention), ingatan (memory) dan pemecahan masalah; sejumlah peneliti yakin bahwa penggunaan strategi yang tidak efektif adalah salah satu penyebab ketidak mampuan belajar (Howard, 2004 atas dasar Deskher, Ellis \& Lenz, 1996).

\section{Model Metakognitif}

Model metakognitif melibatkan berbagai kemampuan berpikir dan proses refleksi selama pembelajaran. Menurut Anderson (2002) model metakognitif terdiri dari lima komponen utama yaitu (1) mempersiapkan dan merencanakan pembelajaran, (2) memilih dan menggunakan strategi, (3) menggunakan strategi serta melakukan pemantauan, (4) mengatur 
berbagai strategi, dan (5) mengevaluasi penggunaan strategi dan belajar. Berikut diuraikan kelima komponen metakognitif.

Mempersiapkan dan merencanakan pembelajaran merupakan keterampilan metakognitif yang dapat meningkatkan pembelajaran (Anderson, 2002). Perumusan tujuan pembelajaran dalam rencana pelaksanaan pembelajaran (RPP) akan melibatkan siswa dalam mempersiapkan belajar dan berpikirnya sendiri untuk mencapai tujuan pembelajaran. Guru dapat membimbing siswa dalam menetapkan tujuan belajar, sehingga akan lebih jelas kemajuan apa yang harus dicapai setelah pembelajaran berakhir. Siswa mempersiapkan pembelajaran dengan memikirkan "apa yang saya perlukan, apa yang ingin saya capai, bagaimana mencapai tujuan tersebut". Tujuan pembelajaran yang jelas dan terukur akan memudahkan siswa dalam menterjemahkan persiapan apa saja yang harus dilakukan, sehingga pada akhirnya dapat menjawab pertanyaan pada akhir pembelajaran.

Memilih dan menggunakan strategi pembelajaran, kemampuan metakognitif untuk memilih dan menggunakan strategi tertentu menunjukkan bahwa siswa dapat berpikir dan membuat keputusan tentang proses pembelajaran (Anderson, 2002). Setelah siswa merencanakan belajar dan berpikir, dilanjutkan membagi tugas dan menetukan strategi dalam kelompoknya untuk mencapai tujuan belajar. Guru membimbing siswa bagaimana memilih strategi pembelajaran yang terbaik agar dapat memecahkan permasalahan. Selain itu, guru juga mengarahkan tentang cara penggunaan strategi yang dipilih. Penggunaan strategi dalam belajar disarankan tidak hanya satu strategi tetapi berbagai macam strategi diperlukan dalam menyelesaikan masalah-masalah yang kompleks. Kerja kolaboratif sangat mendukung diterapkannya berbagai strategi belajar agar pebelajar sukses mencapai tujuan pembelajaran yang diharapkan.

Memonitor penggunaan strategi pembelajaran. Dengan memantau penggunaan strategi pembelajaran, siswa lebih mampu mengendalikan cara belajar dan berpikirnya sendiri untuk memenuhi tujuan pembelajaran (Anderson, 2002). Pemantauan penggunaan strategi yang tepat dapat tergambar dari hasil penyelesaian masalah sebagai tugas-tugas kompleks sesuai dengan jawaban yang diharapkan. Guru harus mengajarkan bagaimana siswa dapat memantau belajar dan berpikirnya saat proses pembelajaran. Kemampuan siswa dalam memantau dan mengendalikan penggunaan strategi pembelajaran akan meningkatkan keterampilan metakognitif siswa.

Mengatur berbagai strategi pembelajaran. Mengetahui cara mengatur penggunaan lebih dari satu strategi pembelajaran merupakan keterampilan metakognitif (Anderson, 2002). 
Siswa yang memiliki keterampilan metakognitif mampu mengorganisiasikan, mengatur, mengasosiasi berbagai strategi yang digunakan. Guru dapat membantu siswa mengajarkan bagaimana menggunakan strategi, kapan strategi tersebut berfungsi atau tidak. Dalam pembelajaran biologi untuk mencari solusi permasalahan diperlukan lebih dari satu solusi misalnya mengumpulkan informasi dengan cara mengakses melalui internet, melalui observasi lingkungan, selanjutnya menganalisis informasi untuk sampai pada sebuah solusi yang tepat.

Mengevaluasi penggunaan strategi pembelajaran. Ketika siswa mengevaluasi strategi yang digunakan, efektif tidaknya dalam menyelesaikan tugas-tugas sulit, maka siswa telah terlibat aktif dalam memberdayakan keterampilan metakognitif (Anderson, 2002). Guru dapat membantu siswa mengevaluasi strategi pembelajaran yang digunakan dengan menanyakan kepada siswa tentang tujuan apa yang ingin dicapai, strategi apa yang digunakan, seberapa baik menggunakan strategi, dan apalagi yang bisa dilakukan. Kemampuan siswa dalam mengevaluasi strategi yang digunakan melibatkan keterampilan berpikir tentang cara belajar dan berpikirnya sendiri. Hal ini akan dapat meningkatkan kemandirian siswa dalam belajar.

Dari keseluruhan komponen metakognitif yang diuraikan di atas, guru seharusnya menerapkan secara utuh siklus pembelajaran tersebut. Karena kelima komponen model metakognitif dalam proses pembelajaran saling berinteraksi, menguatkan, dan menumbuhkan aktivitas-aktivitas kognitif dan metakognitif siswa.

\section{Peran Metakognitif dalam Pembelajaran dan Pengajaran Biologi}

Pembelajaran biologi sangat erat dengan kehidupan sehari-hari yang sangat kompleks dengan berbagai permasalahan nyata di sekelilingnya. Demikian pula pengajaran dan pembelajaran sains adalah proses yang kompleks dari isi maupun keterampilan berpikir yang diperlukan untuk memahami secara mendalam (Hartman, 2001). Hal inilah yang mendorong siswa agar memiliki keterampilan sebagai pemecah masalah yang handal. Pemecahan masalah dan solusinya tentu saja tidak dapat diperoleh secara instan tetapi memerlukan proses pembiasaan dan latihan selama pembelajaran. Dengan memberdayakan keterampilan metakognitif dalam pembelajaran dan pengajaran, melalui tugas-tugas yang kompleks akan melatih siswa menjadi self regulated dan pemecah masalah. Sesuai pendapat Millis (2016), guru sebagai perancang pembelajaran perlu mendesain pembelajaran yang mempromosikan metakognitif mulai pada kegiatan awal pembelajaran, kegiatan inti, dan kegiatan akhir pembelajaran.

Kegiatan awal pembelajaran. Pada kegiatan awal pembelajaran guru melakukan kegiatan yang mengarahkan siswa untuk menunjukkan pengetahuan awal tentang konsep 
yang telah diberikan, proses belajar, dan kemampuan memantau pemecahan masalah yang telah dilakukan. Melalui kegiatan ini kesadaran metakognitif siswa dapat ditingkatkan. Menurut Angelo \& Cross (1993) ada tiga kegiatan di awal pembelajaran yang mempromosikan metakognitif yaitu (1) siswa menuliskan konsep-konsep yang diingat dengan waktu tidak lebih dari dua menit, (2) siswa menjelaskan atau mendefinisikan konsep dengan kata-kata sendiri, dan (3) siswa memberikan contoh apa yang sudah dijelaskan dari konsep-konsep. Dengan demikian kegiatan awal pembelajaran penting dilakukan untuk mengetahui kemampuan dan pengetahuan awal siswa dan memberikan umpan balik siswa. Diperkuat oleh Millis (2016) kesadaran metakognitif siswa perlu dibangun selama pembelajaran, baik pada kegaiatan awal, kegiatan initi maupun kegiatan akhir pembelajaran.

Kegiatan selama pembelajaran. Selama pembelajaran di kelas, kegiatan-kegiatan dioptimalkan menuju pemberdayaan metakognitif (Millis, 2016). Menurut Johnson and Cooper (2003) ada tiga contoh "berpikir cepat" yang dikembangkan selama pembelajaran yaitu (1) siswa diberi pertanyaan terbuka atau siswa harus melengkapi kalimat yang belum sempurna, (2) siswa membandingkan dua hal yang parallel, membuat koneksi antara keduanya, dan (3) mendukung sebuah pernyataan, siswa harus memberi dukungan dengan menggunakan berbagai sumber pustaka. Kegiatan ini akan merefleksikan siswa tentang apa yang mereka ketahui dan yang tidak diketahui.

Kegiatan selama pembelajaran atau disebut juga kegiatan inti memiliki alokasi waktu paling banyak, sebab banyak aktivitas-aktivitas kognitif dan metakognitif siswa yang dapat dikembangkan melalui sintaks model pembelajaran yang digunakan guru. Telah terbukti dari hasil penelitian bahwa penggunaan model pembelajaran mempengaruhi efektifitas pembelajaran termasuk pemberdayaan keterampilan metakognitif dan hasil belajar siswa. Corebima (2010) menyatakan bahwa ada pengaruh strategi pembelajaran terhadap keterampilan metakognitif. Penelitian Bahri (2016) dengan strategi PBL dan RQA, Listiana et al., (2016) dengan strategi GI dan TTW, Tumbel (2011) dengan strategi Kooperatif Script dan Problem Posing mengungkapkan berpengaruh terhadap keterampilan metakognitif dan pemahaman konsep biologi.

Kegiatan setelah pembelajaran. Setelah pembelajaran kegiatan menggunakan pendekatan metakognitif dilakukan dengan "Half-Sheet Response" yaitu siswa menulis tanggapan dari dua pertanyaan pada kartu sebagai tiket untuk keluar kelas. Pertanyaan antara lain tentang kesan penting dalam pembelajaran hari ini dan pertanyaan apa yang belum terjawab (Millis, 2016). Melalui pertanyaan ini mendorong siswa merefleksikan pemahaman 
tentang materi yang baru dipelajari. Kegiatan ini melatihkan siswa memonitor sendiri tentang pemahamannya, sehingga pada akhirnya dapat memilih dan menggunakan strateginya untuk meningkatkan pemahaman terhadap konsep yang sulit.

Pemberian tugas-tugas rumah sebagai tindak lanjut pembelajaran diletakkan pada kegiatan setelah pembelajaran. Melalui tugas-tugas yang kompleks akan meningkatkan daya pikir, kemampuan kognitif, dan metakognitif siswa. Hal ini diperkuat penelitian Mota, et al., (2019) strategi pekerjaan rumah (homework) penting dirancang untuk membantu mengembangkan self asesmen, metakognisi, dan keterampilan memecahkan masalah secara kolaboratif. Temuannya pendekatan pekerjaan rumah meningkatkan kualitas keterampilan metakognitif siswa.

Oleh sebab itu pemberian tugas-tugas di rumah menjadi penting diterapkan untuk setiap mata pelajaran. Pada saat mengerjakan tugas secara berkelompok setiap individu didorong untuk membagi tugas, merencanakan strategi, lalu menggunakannya untuk memahami konsep dan mencari solusi permasalahan. Pemantauan dan asesmen terhadap hasil tugas juga dilakukan dalam kelompok. Hal ini akan mendorong pengembangan metakognitif siswa, membantu menjadi lebih reflektif dan sadar akan proses pemecahan masalahnya sendiri.

\section{Hambatan Penerapan Metakognitif}

Kurikulum 2013 yang berlaku saat ini sudah sangat kondusif untuk mengembangkan keterampilan metakognitif siswa, akan tetapi penerapan keterampilan metakognitif dalam pembelajaran masih mengalami hambatan-hambatan. Antara lain masih dominannya peranan guru di kelas, guru sebagai sumber satu-satunya dalam pembelajaran. Hal ini menjadikan pembelajaran dengan metode ceramah masih banyak dilakukan. Akibatnya siswa kurang terlibat aktif dalam pembelajaran, mereka lebih banyak menerima, mendengarkan, dan menuliskan informasi-informasi dari guru.

Hambatan lain, sistem penilaian dalam pendidikan kita masih banyak yang berorientasi pada hasil bukan pada proses. Misalnya perolehan nilai ujian akhir atau nilai kelulusan menjadi tujuan utama pembelajaran, sementara penilaian terhadap proses pembelajaran sangat kurang. Sementara itu pengembangan keterampilan berpikir, keterampilan membuat planning, keterampilan mengatur strategi belajar dan berpikir, memantau dan mengevaluasi hasil belajarnya sendiri dapat dioptimalkan selama proses pembelajaran. Demikian pula dengan bentuk penilaian terhadap hasil belajar siswa cenderung menggunakan bentuk pilihan ganda, menjodohkan, dan isian singkat, dengan butir soal yang diberikan masih pada tingkat kemampuan kognitif rendah yaitu mengingat dan memahami. 
Pembelajaran biologi dengan permasalahan kompleksnya terkait lingkungan dan kehidupan sehari-hari sangat memfasilitasi dipromosikannya keterampilan metakognitif. Akan tetapi masih ada beberapa kendala atau hambatan dalam penerapan metakognitif di kelas, yaitu (1) kesulitan dalam mengembangkan lembar kerja mahasiswa (LKM) atau lembar kerja siswa (LKS) dalam membuat soal-soal latihannya. Dengan lembar kerja ini guru dapat menuangkan langkah-langkah kerja siswa yang mendorong munculnya keterampilan berpikir, menganalisis, mensintesis, mengevaluasi dan menyimpulkan. Serta keterampilan mengorganisiasi, merencanakan, mengatur dan menggunakan strategi untuk pemecahan masalah; (2) Kesulitan dalam membuat soal-soal yang melatihkan keterampilan berpikir tingkat tinggi seperti berpikir kritis, berpikir kreatif, pemecah masalah dan keterampilan metakognitif; (3) waktu yang tersedia tidak cukup untuk melakukan pembelajaran yang memberdayakan keterampilan metakognitif (Iskandar, 2014).

Hambatan-hambatan dalam penerapan metakognitif selama pembelajaran seharusnya memang dapat dicarikan solusinya. Pemberlakuan Kurikulum 2013 akan menguatkan diterapkannya pembelajaran metakognitif didukung dengan fasilitas dan pengembangan kompetensi guru-guru melalui pemantapan, pelatihan, atau workshop pembelajaran terkait pengembangan perangkat pembelajaran dan implementasinya.

\section{Dampak Penerapan Metakognitif}

Pembelajaran dengan mengembangkan metakognitif sangat baik diterapkan di kelas saat kegiatan awal, kegiatan inti dan kegiatan akhir pembelajaran. Karena penerapan metakognitif ini ada pengaruh strategi metakognitif terhadap kemampuan berpikir tingkat tinggi. Strategi metakognitif dalam pembelajaran meliputi tiga tahap, yaitu merancang apa yang dipelajari; memantau perkembangan diri dalam belajar; dan menilai apa yang dipelajari. Strategi metakognitif dapat digunakan untuk setiap pembelajaran apapun. Guru dapat mengarahkan siswa secara sadar mengontrol proses berpikir mereka. Sesuai pendapat Marthan \& Koedinger (2005) menyatakan bahwa guru dapat meningkatkan penggunaan strategi metakognitif dalam membahas suatu konsep yang baru dengan mengingatkan kembali apa yang sudah diketahui siswa sebelumnya.

Metakognitif dapat digolongkan pada kemampuan kognitif tinggi karena memuat unsur analisis, sintesis, dan evaluasi sebagai cikal bakal tumbuh kembangnya kemampuan inkuiri dan kreativitas (Schraw and Moshman, 1995). Oleh karena itu pelaksanaan pembelajaran semestinya membiasakan siswa untuk melatih kemampuan metakognitif ini, tidak hanya berpikir sepintas dengan makna yang dangkal (Ambrose, et al.2010). Pembelajaran 
metakognitif di kelas biologi yang dilatihkan secara kontinyu mulai kegiatan awal sampai akhir pembelajaran, maka kemampuan berpikir tinggi akan berkembang dan menjadi terampil. Siswa yang belajar dengan pembelajaran metakognitif dengan baik, memiliki jenis keterampilan berikut yakni keterampilan pemecahan masalah, keterampilan pengambilan keputusan, keterampilan berpikir kritis dan keterampilan berpikir kreatif. Hal ini sejalan dengan pendapat Dawson \& Fuhcer (2008) bahwa siswa-siswa yang menggunakan metakognitifnya dengan baik akan menjadi pemikir yang kritis, problem solver yang baik, serta pengambil keputusan yang baik dari pada mereka yang tidak menggunakan metakognisinya.

\section{SIMPULAN}

Metakognitif memegang peranan penting dalam pembelajaran dan pengajaran biologi. Metakognitif terdiri dari (1) pengetahuan metakognitif, meliputi tiga kategori yaitu variabel individu, variabel tugas, dan variabel strategi, (2) pengalaman/regulasi metakognitif (metakognitive experience or regulation) disebut juga strategi metakognitif, merupakan proses-proses berfokus pada planning, monitoring, controling dan evaluation. Strategi metakognitif dapat diimplentasikan melalui model pembelajaran metakognitif yang terdiri dari lima komponen utama metakognitif, yaitu (1) mempersiapkan dan merencanakan pembelajaran, (2) memilih dan menggunakan strategi, (3) menggunakan strategi serta melakukan pemantauan, (4) mengatur berbagai strategi, (5) mengevaluasi penggunaan strategi dan belajar. Kelima komponen utama metakognitif tersebut harus diterapkan guru selama pembelajaran secara utuh, karena terbukti dapat meningkatkan keterampilan siswa dalam pemecahan masalah. Oleh sebab itu guru harus merancang perangkat pembelajaran yang mempromosikan metakognitif dan implementasikan mulai pada kegiatan awal pembelajaran, kegiatan inti, dan kegiatan setelah pembelajaran. Agar tujuan pembelajaran tercapai dan siswa memiliki keterampilan metakognitif yang baik.

\section{REFERENSI}

Ambrose, S.A., et al., 2010. How Learning Works: 7 Research-Based Principles for Smart Teaching. San Francisco, CA: Jossey-Bass.

Anderson, N. J. 1999. Exploring Second Language Reading: Issues and Strategies. Boston: Heinle \& Heinle.

Angelo, T. A. \& Cross, K. P. 1993. Classroom assessment techniques: A handbook for college teachers (2nd ed.). San Francisco, CA: Jossey-Bass. 
Bahri, A. \& Idris, Irma S., 2017. Teaching Thinking: Memberdayakan Keterampilan Metakognitif Mahasiswa melalui PBLRQA (Integrasi Problem Based Learning dan Reading, Questionong, \& Answering). Proceeding of National Seminar. Universitas Negeri Makasar.

Brown, A.L. 1987. Metacognition, Executive Control, Self-regulation, and Other More Mysterious Mechanisms. In F.E. Weinert \& R.H. Kluwe (Eds.). Metacognition, Motivation, and Understanding (pp.65-116). Hillsdale, New Jersey: Lawrence Erlbaum Associates.

Corebima, A.D. 2010. Berdayakan Keterampilan Berpikir dan Kemampuan Metakognitif Selama Pembelajaran Sains Demi Masa Depan Kita. Makalah disajikan dalam Seminar Nasional Sains, Universitas Negeri Surabaya. Surabaya, 16 Januari.

Dawson, Th \& Fucher, K. 2008. Metacognition and Learning Adulthood. Contemporary Education Psychology, 11, 233-236.

Flavell, J.H., 1979. Metacognition and Cognitive Monitoring: A new Area of Cognitive Developmental Inquiry. American Psychologist, 1979. 34(10): p. 906-911.

Hartman, Hope J., 2001. Metacognition in Science Teaching and Learning. Metacognition in Learning and Instruction. pp 173-201. Kluwer Academic Publisher.

Howard, J.B. 2004. Metacognitive Inqury. School of Education. Elon University.

Iskandar, Srini M. 2014. Pendekatan Keterampilan Metakognitif dalam Pembelajaran Sains di Kelas. Erudio, Vol.2, No.2, ISSN: 2302-9021 Desember 2014.

Johnson, S. \& Cooper, J. 2003. Quick thinks: Active-thinking tasks in lecture classes and televised instruction. In J. L. Cooper, P. Robinson, \& D. Ball (Ed.), Small group instruction in higher education: Lessons from the past, visions for the future ( $p p .122$ 134). Stillwater, OK: New Forums Press.

Listiana, L., Susilo, H., Suwono, H., \& Suarsini, E., 2016. Empowering Students 'Meta Cognitive Skills Through New Teaching Strategy (Group Investigation Integrated With Think Talk Write) In Biology Classroom. Journal of Baltic Science Education, Vol. 15, No. 3, 2016. ISSN 1648-3898.

Livingston, J. 1997. Metacognition: an Overview. Retrieved (Online)(http://www.gse.buffalo.edu/fas/shuell/cep564/metacog.htm.

Marthan, S \& Koedinger, K, 2005, Fostering the Intelligent novice: Learning from Error with Metacognitive Tutoring. Educational Psychology, 89(4), 686-695.

Millis, Barbara J. 2016. Using Metacognition to Promote Learning. IDEA Center Inc. ERIC Number: ED573671.

Mota, Ana R., Korhasan, Nilufer D., Miller, Kelly., and Mazur, Eric., 2019. Homework as a Metacognitive Tool in an Undergraduate Physics Course. Physical Review Physics education Research 15, 010136.

Pintrich, P.R., 2002. The Role of Metacognitive Knowledge in Learning, Teaching, and Assessing. Theory into Practice, 2002. 41(4): p. 219-225.

Schraw, G. and D. Moshman, 1995. Metacognitive Theories. Educational Psychology Review, 1995. 7(4): p. 351-371.

Tarricone, P., 2011. The Taxonomy of Metacognition. 2011. New York, NY: Psychology Press.

Tumbel, F.E. 2011. Pengaruh Strategi Pembelajaran Cooperative Script Dipadu Problem Posing dan Kemampuan Akademik Siswa Terhadap Keterampilan Metakognitif, 
Kemampuan Berpikir dan Pemahaman Konsep Biologi pada SMA di Kota Bitung Sulawesi Utara. Disertasi tidak diterbitkan. Malang: PPs Universitas Negeri Malang.

Whitebread, D., et al., 2007. Development of Metacognition and Self-Regulated Learning in YoungChildren: Role of Collaborative and Peer-Assisted Learning. Journal of Cognitive and Educational Psychology, 2007. 6(3): p. 433-455. 